\title{
Industry 4.0 and Circular Economy: Integrated or disarticulated concepts? A research agenda
}

Fabiana Liar Agudo ${ }^{1}$, São Paulo State University, Bauru, São Paulo, Brazil

José Alcides Gobbo Júnior², São Paulo State University, Bauru, São Paulo, Brazil

Simone Cristina de Oliveira Gobbo ${ }^{3}$, São Paulo State University, Bauru, São Paulo, Brazil

\section{RESUMO}

Objetivo - Analisar se os conceitos de indústria 4.0 e economia circular são integrados ou desarticulados, reconhecendo na literatura quais palavras-chave são mais frequentes nesta relação e sua ocorrência.

Metodologia - O método de pesquisa foi o estudo bibliométrico e estudo de palavras-chave, com a finalidade de reconhecer quais são as ações e estratégias mais latentes no estudo da integração. Foi utilizado o software VOSviewer para o estudo de palavras-chave.

Resultados - Afirma-se que os conceitos de indústria 4.0 e economia circular podem ser considerados interligados, com algumas limitações exploradas no artigo, e propôs também oportunidades futuras de pesquisas sobre o tema.

Contribuições - Contribui para os gestores de negócios no sentido de que facilita o entendimento de que a indústria 4.0 e a economia circular podem ser trabalhados juntos. O resultado das palavras-chave norteará quais habilidades, estratégias, tecnologias e fundamentos a empresa deverá desenvolver para efetivar a economia circular, por meio da indústria 4.0. Para pesquisas acadêmicas, contribuiu-se com mais um estudo sobre a integração da indústria 4.0 e economia circular, que são poucos na literatura. Também foram mapeadas palavras-chave, que até então, não haviam sido desenvolvidas em artigos de integração existentes, além de propor um framework que pode ser transformado e sinalizar oportunidades de pesquisa.

Palavras-chave - Indústria 4.0; Economia Circular; Integração; Sustentabilidade; Pesquisas futuras.

\section{ABSTRACT}

Purpose - To analyze whether the concepts of industry 4.0 and circular economy are integrated or disjointed, recognizing in the literature what the keywords are most frequent in this relationship and its occurrence.

Design/methodology/approach - The research method was the bibliometric study and keyword study, in order to recognize which are the most latent actions and strategies in the study of integration. The VOSviewer software was used for the study of keywords.

Findings - It is stated that the concepts of industry 4.0 and circular economy can be considered interconnected, with some limitations explored in the article, and also proposed future research opportunities on the topic.

Originality/value - It contributes to business managers in the sense that it facilitates the understanding that industry 4.0 and the circular economy can be worked together. The result of the keywords will guide what skills, strategies, technologies and fundamentals the company should develop to make the circular economy effective, through industry 4.0. For academic research, another study was contributed on the integration of industry 4.0 and circular economy, which are few in the literature. Keywords were also mapped, which until then, had not been developed in existing integration articles, in addition to proposing a framework that can be transformed and signal research opportunities.

Keywords - Industry 4.0; Circular Economy; Integration; Sustainability; Future research.

1. Av. Engenheiro Luiz Edmundo Carrijo Coube, 14-01. PO BOX 17033-360, Bauru, São Paulo, Brasil, fabiana.liar@yahoo.com.br, https://orcid.org/0000-0002-7517-5505; 2. jose.gobbo@unesp.br, https://orcid.org/0000-0002-0065-7235; 3. simone.o.gobbo@gmail.com, https://orcid.org/0000-0001-5241-9872

AGUDO, F.L.; GOBBO JUNIOR, J.A.; GOBBO, S.C.O. Industry 4.0 and Circular Economy: Integrated or disarticulated concepts? A research agenda GEPROS. Gestão da Produção, Operações e Sistemas, v.15, no 4, p. 48 - 77, 2020.

DOI: http://dx.doi.org/10.15675/gepros.v15i4.2771 


\section{INTRODUCTION}

In the context of business competition, it is essential concern with environmental factors and the expanding the use of new technologies. Demanding consumers and environmentally responsible expect high levels of innovation, and more agile responses, so pressure the forms of competition from companies in global markets.

Industry 4.0 is a recent trend that employs a technology package, for the purpose to increase productivity, speed up the exchange of information, precision in decision making, and a differentiation in how to respond customer's requests (ISSAMAR; ROBERTO, 2019). In reference of the environmental issue, one of the main challenges of the current economic system is the growing demand for resources due to large-scale production, which goes against the planet's ability to provide these resources and absorb the waste generated in industrial processes (SAHIMMA et al., 2017; NASIR et al., 2017).

Soon, think of a strategy, that maintains efficiency, meet consumer desires, and balance the environmental impact, it's a challenge, which the circular economy (CE) been trying to answer, being the industry 4.0 a possibility to achieve the shift from a linear to circular economy and sustainable supply chain (RAJPUT; SINGH, 2019).

The integration between these trends will revolutionize how to understand the pattern of consumption and production. Success factors, able to drive industry 4.0 for sustainable manufacturing, should be weighted, such as: managerial leadership, readiness for change, top management commitment, strategic alignment, training and capacity, empowerment, team work, organizational culture, communication, project management, and national culture and regional differences (SOUSA JABBOUR et al., 2018b).

Despite the acquired relevance, the integration between the concepts of industry 4.0 and the $\mathrm{CE}$ tends to be exploited, which contributes to the generation of a gap in this field of knowledge (GAZZOLA et al., 2019; NASCIMENTO et al., 2019). Aligned to this gap in the literature, the objective of this article is to analyze whether the concepts of industry 4.0 and $\mathrm{CE}$ are integrated or disjointed, recognizing in the literature what the keywords are most frequent in this relationship and its occurrence.

To achieve the objective, the research method chosen was the bibliometric study and study of keywords, with the purpose of recognizing what are the actions and more latent strategies in the study of integration between industry 4.0 e CE. Bibliometric methods are 
firmly established in the field of scientific research, and the number of publications that use this tool has gradually increased in recent years (ELLEGAARD; WALLIN, 2015; ROJAS LUIZ et al., 2016; GOBBO JÚNIOR et al., 2018).

This article consists of 5 sections, of which: section 2 addresses the theoretical background about industry 4.0 and CE; section 3 brings the method used for the development of the study, section 4 the results and discussions and, section 5 the conclusion and suggestions for future work.

\section{LITERATURE REVIEW}

\subsection{Integration between Industry 4.0 and Circular Economy}

Known as the fourth industrial revolution, industry 4.0 is a recent approach in organizations and represents the current production paradigm, combining information and communication technologies (ICT) with digital manufacturing technologies (KANG et al., 2016). Industry 4.0 adopts several technologies and principles (BAHRIN et al., 2016; GHOBAKHLOO, 2018). A summary of the most relevant technologies and principles in industry 4.0 can be seen in Table 1 .

Table 1 - Enabling technologies and principles of Industry 4.0.

\begin{tabular}{|c|c|c|}
\hline $\begin{array}{c}\text { ENABLING } \\
\text { TECHNOLOGIES } \\
\text { AND PRINCIPLES }\end{array}$ & CONCEPT & AUTHORS \\
\hline Cloud computing & $\begin{array}{l}\text { Virtualization service where data is stored on a platform } \\
\text { accessible by internet, ubiquitous access, and with } \\
\text { flexible capacity customer's needs. }\end{array}$ & $\begin{array}{l}\text { (ZHAN et al. 2015, WAN } \\
\text { et al. 2016, FRANK et al., } \\
\text { 2019, LU; XU, 2019) }\end{array}$ \\
\hline Blockchain & $\begin{array}{l}\text { Technology to encrypt data, allowing security in the } \\
\text { transmission of information between agents in the chain. }\end{array}$ & IVANOV et al., 2019 \\
\hline Augmented reality & $\begin{array}{c}\text { Interaction of virtual and physical environment, with a } \\
\text { visualization technology, a camera, a tracking system and } \\
\text { the user interface. }\end{array}$ & $\begin{array}{l}\text { MASSOD; EGGER, } \\
\text { 2019, GATTULLO et al., } \\
2019\end{array}$ \\
\hline $\begin{array}{l}\text { Automation and } \\
\text { robotization }\end{array}$ & $\begin{array}{l}\text { Use of robots to perform high-risk jobs and replacement } \\
\text { of man for precision gain and productivity. }\end{array}$ & $\begin{array}{l}\text { BAHRIN et al., 2016., } \\
\text { WAHRMANN et al., } \\
2019\end{array}$ \\
\hline Additive manufacturing & $\begin{array}{l}\text { Product prototyping, printing units, spare parts on 3D } \\
\text { printers. }\end{array}$ & $\begin{array}{l}\text { FRANCIS; BIAN, 2019, } \\
\text { WAHRMANN et al., } \\
2019\end{array}$ \\
\hline $\begin{array}{l}\text { Simulation and } \\
\text { modeling }\end{array}$ & $\begin{array}{l}\text { Use of computational resource for simulation and creating } \\
\text { models that replicate factory environments and parts. It } \\
\text { can happen with the use of virtual reality. }\end{array}$ & $\begin{array}{l}\text { MOEUF et al. } 2018 \\
\text { DINIS, } 2020\end{array}$ \\
\hline Digital manufacturing & $\begin{array}{l}\text { Advanced data processing application, as well as cloud } \\
\text { technologies, for higher levels of automation. }\end{array}$ & $\begin{array}{l}\text { BENDUL; BLUNCK, } \\
2019\end{array}$ \\
\hline Digital security & $\begin{array}{l}\text { Code of practice for information security management to } \\
\text { avoid loss of customers and contracts, image damage and }\end{array}$ & WAN et al. 2016 \\
\hline
\end{tabular}




\begin{tabular}{ccc}
\hline & \multicolumn{2}{c}{ ruin of intellectual property. } \\
\hline Systems integration & $\begin{array}{c}\text { Integration is one of the great differentials of industry 4.0. } \\
\text { Can be integrated vertically between resources from the } \\
\text { factory itself, or horizontally, between members of a } \\
\text { supply chain. }\end{array}$ & $\begin{array}{c}\text { SONY, 2018, GU et al., } \\
\text { 2019 }\end{array}$ \\
\hline IoT & $\begin{array}{c}\text { Digital connection of physical objects to capture data, that } \\
\text { can be used for the material recycling process. }\end{array}$ & $\begin{array}{c}\text { LIN, 2018, MARQUES; } \\
\text { PITARMA, 2019 }\end{array}$ \\
\hline Cyber physical systems & $\begin{array}{c}\text { Monitor physical processes, create a virtual copy of the } \\
\text { physical space and execute decentralized decisions. }\end{array}$ & $\begin{array}{c}\text { STRANDHAGEN et al., } \\
\text { 2017, JANG et al., 2020 }\end{array}$ \\
\hline Big data & $\begin{array}{c}\text { Collects, stores and processes data for planning and } \\
\text { control of manufacturing operations. }\end{array}$ & LU, XU, 2019, \\
\hline
\end{tabular}

Source: The authors.

Geissdoerfer et al. (2017) define CE as a regenerative system in which resource input and waste, emission, and energy leakage are minimized by slowing, closing, and narrowing material and energy loops. The CE comes from different schools of thought, being the Pearce and Turner economists, those responsible for introducing in 1989, the design of circular economic system.

$\mathrm{CE}$ schools of thought have been perfected over time, and current approaches to operationalize circular models (Table 2), according to the Ellen MacArthur Foundation (2017), are:

Table 2 - Circular economy schools of thought.

\begin{tabular}{|c|c|c|}
\hline $\begin{array}{l}\text { SCHOOLS OF } \\
\text { THOUGHT }\end{array}$ & CONCEPT & AUTHORS \\
\hline Regenerative Design & $\begin{array}{l}\text { Product projection, that even before it were functional, } \\
\text { being thought and created to maximize their useful life, } \\
\text { restoring sources of energy and materials through reuse, } \\
\text { remanufacturing and recycling. }\end{array}$ & $\begin{array}{l}\text { COLE, 2012, LIEDER } \\
\text { et al., 2017, LYLE } \\
\text { CENTER, } 2019\end{array}$ \\
\hline $\begin{array}{l}\text { Performance } \\
\text { Economy }\end{array}$ & $\begin{array}{c}\text { School that defends that an item should have its useful life } \\
\text { extended. Technology and knowledge gains can contribute } \\
\text { so that the economic use of the product / service is } \\
\text { extended. }\end{array}$ & STABEL, 2010 \\
\hline From cradle to cradle & $\begin{array}{l}\text { For this approach, there should be no waste in the industry, } \\
\text { since the residue of a certain segment would be the starting } \\
\text { raw material for another, in a circular logic of creation and } \\
\text { reuse. }\end{array}$ & $\begin{array}{l}\text { MIRABELLA et al., } \\
\text { 2014, SWAIN, } 2017 \text {, } \\
\text { KOPNINA, } 2019\end{array}$ \\
\hline Industrial ecology & $\begin{array}{l}\text { Study material and energy flows, employing precepts of } \\
\text { ecology in industry. One of the concepts used in this } \\
\text { school is industrial symbiosis (IS). }\end{array}$ & $\begin{array}{l}\text { EHRENFELD; } \\
\text { GERTLER, 1997, } \\
\text { CHERTOW, 2000, } \\
\text { CHERTOW, 2007 }\end{array}$ \\
\hline Biomimicry & $\begin{array}{l}\text { Analyzes the behavior of nature agents and try to imitate it } \\
\text { to avoid problems of a human nature. }\end{array}$ & $\begin{array}{l}\text { GEISENDORF; } \\
\text { PIETRULLA, } 2018\end{array}$ \\
\hline Blue Economy & $\begin{array}{l}\text { Movement that gather case studies for turning problems } \\
\text { into opportunity low cost solution for the environment. }\end{array}$ & $\begin{array}{l}\text { ABERKANE, 2017, } \\
\text { BLOMSMA, } 2018\end{array}$ \\
\hline
\end{tabular}

Source: The authors. 
Integration between industry 4.0 concepts and technologies and environmental aspects is a promising business trend and necessary for organizational development (GOBBO JÚNIOR et al., 2018). One of these integration trends refers to the CE and Industry 4.0.

Directed in seeking like industry 4.0 can facilitate the deployment of circular economic processes, the literature presents low volume of publications on the subjects in an integrated way (JABBOUR et al., 2019a, NASCIMENTO et al. 2019), being necessary there is expansion of theoretical and empirical studies to check the level of integration and its occurrence relationship.

Okorie et al. (2018) indicates that research integrating industry 4.0 and CE are developed, mainly, in the areas of knowledge Computer Science and Engineering, reflecting in an interdisciplinary character with technological perspectives economic, organizational and adaptation frameworks (cognitive), being the $\mathrm{R}$ recycling, reform, remanufacturing and reuse, those who recorded the highest proportion of results.

An industry 4.0 virtual network can uncomplicate engineering end-to-end, connecting customers, employees, suppliers and equipment, that exchange data between the different phases of the product life cycle (STOCK; SELIGER, 2016). The employment of IoT encourages agents to achieve a long-term sustainable supply chain (MANAVALAN; JAYAKRISHNA, 2019).

It should be noted that the Product Service System is seen by industry 4.0 as trend for the transformation of traditional industries into digital factories (LEE et al., 2014), as well as by the $\mathrm{CE}$ as a possibility of extending the life of a product, and material reduction (TUKKER, 2015), another possible point of interconnection between concepts addressed in this work (BRESSANELLI et al., 2018b).

Similarly, the IoT, cloud computing, CPS, and additive manufacturing were pointed out in the studies of Jabbour et al. (2019b) and Sousa Jaboour et al. (2018a) as a possibility to institute the structure RESOLVE in companies. In addition, research proposals like to identify technologies and 4.0 industry resources to advance the $\mathrm{CE}$ and the relationship between the two concepts, in search of sustainability, were placed.

Tseng et al. (2018) proposes the use of big data to evaluate the trust and behavior corporate between suppliers in a supply chain, in order to improve symbiosis. Another proposal for big data is the use of data analysis to improve resource efficiency, extend product life and close the circle of CE (BRESSANELLI et al., 2018a). The data exchange that this 
technology allows dealing with material composition and sharing issues of recycling optimization or reuse between partners (JENSEN; REMMEN, 2017).

In general, using sensors, embedded systems, internet connected devices (IoT) and a database (LIN, 2018), the machine gets integrated information, aadapt manufacturing operations through self-optimization, update routines in real time. Real-time information allows point out cell failures in production, avoiding material loss; collect energy values, when managing peak periods; recognize what stage of life the product is in, facilitating remanufacturing programming and component reuse; and finally, track the product in the chain to manage strategic recycling points (YANG et al., 2018; YAZDI et al., 2018; MARTÍN-GÓMEZ et al., 2019).

So, enabling technologies have the potential to introduce the concept of $\mathrm{CE}$ and overcome operationalization challenges, smoothing the supply chain transition of a linear model for circular (BRESSANELLI et al., 2018b; GARCIA-MUIÑA et al., 2018; SALAH et al., 2019; SING et al., 2019; TSENG et al., 2019).

Due to industry 4.0 having a diversity of technologies, and the CE has several approaches to implementation, as well as the concepts being emergent and complex, it is essential to formulate an integrative structure (BLOMSMA; BRENNAN, 2017; OKORIE et $a l ., 2018)$. Figure 1 represents the integration between industry 4.0 and the CE. In the center of the figure, the schools that guide the application of the CE with the tools of industry 4.0. The joint use of enabling technologies contributes to the implementation of the $\mathrm{CE}$ and consequently for organizational sustainability. 
Figure 1 - Framework the integration between industry 4.0 and CE

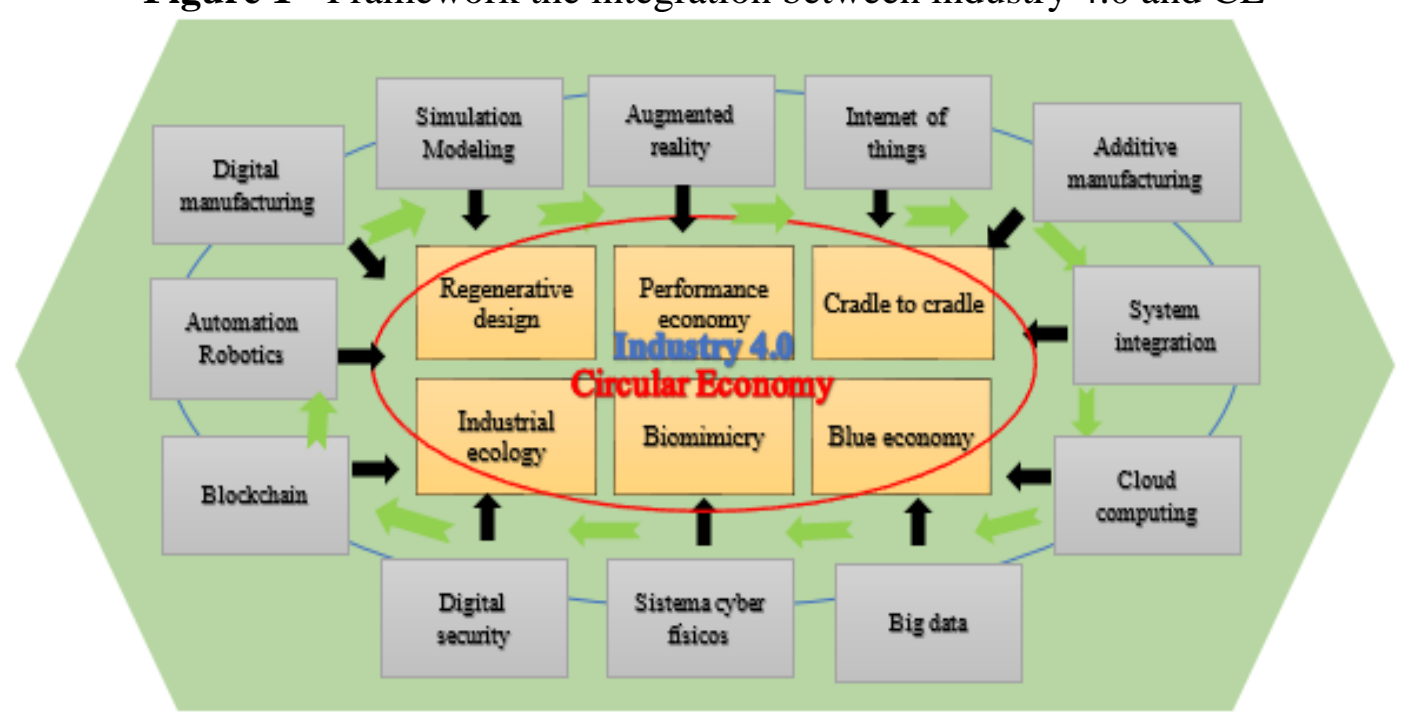

Source: The authors.

Aiming to answer how enabling technologies may be integrated into the practice of $\mathrm{CE}$, and what characteristics should be considered, Nascimento et al. (2019) suggests a business model of the circular intelligent production system, involving industry 4.0, CE, sustainable supply chain management and additive manufacturing. Thus, in order to contribute to the discussion of integration between industry 4.0 and CE, a study of keywords was carried out, in theoretical and practical studies, aiming to identify which other tools, policies and strategies can be coupled in the study of integration.

\section{METHODOLOGICAL PROCEDURES}

The focus of the research was a bibliometric review the co-occurrence of keywords. The bibliometric study is a method to know the contributions of the literature about a certain topic being applied in several research areas (AHMED; HUANG, 2019; HAFEZALKOTOB et al., 2019). Ellis et al. (2019), López-Robles (2019) and Wang and Yang (2019) bibliometrics is a common form of investigation and accepted for the study of literature, generally producing information about published documents, citations received, impact factor of journals, most cited authors and key words in order to offer insights on the general development of research.

The theoretical background addresses industry 4.0 topics 4.0, CE and integration between the two concepts, whose materials have theoretical and empirical character. The 
databases chosen for the analysis of the keywords were Scopus and Web of Science, for its representativeness, credibility and volume of international publications. The option for two bases suitable to guarantee a comparative and the scope of verification more embracing.

The search strings were: "INDUSTRY 4.0", "CIRCULAR ECONOMY", "INDUSTRY 4.0" AND “CIRCULAR ECONOMY”, "SMART INDUSTRY” AND "CIRCULAR ECONOMY”, “ADVANCED MANUFACTURING” AND "CIRCULAR ECONOMY" and "FOURTH INDUSTRIAL REVOLUTION" AND "CIRCULAR ECONOMY". The terms were searched for in the article title, abstract and keywords.

The data collection of the journals happened in the first half of May 2019, being applied as an inclusion criterion the "article" filter, due to its selection and solidity in the literature. The journals collected on industry 4.0 are dated 2012-2019, CE's from 2004-2019 and integration between industry 4.0 and CE from 2011-2019. Subsequently the search and application of the filter, the articles were saved to the extent acceptable by the software, and words that had at least a 2-fold occurrence level, its occurrence was extracted and strength ratio.

For the study of words, the VOSviewer software was used, version 1.6.8, in order to form co-occurrence of the terms, that indicate the number of times that two terms occur together in a set of documents, and use the similarity of the occurrence as a strength of association (VAN ECK; WALTMAN, 2010; KAMDEM et al., 2019; REDEKER et al., 2019). The VOSviewer generates a visual map, where the bigger for the level of occurrence of the keywords, the circular shape of the word is denser (LAWAL, 2019).

The abstract and keywords were imported in extension CSV of Scopus database, and the full record extension and the full record extension of Web of Science database. Through the results, the keyword network was formed and their relationships analyzed to check if the concepts of industry 4.0 and CE are interconnected.

\section{RESULTS AND DISCUSSIONS}

As of consultation the base Scopus, the search string "industry 4.0" resulted in 4801 documents. Using the include filter, that number reduced to 1612 articles. With the string "circular economy" 3810 documents were found, that after using the inclusion filter, were to 2143 articles. However, as this basis limits data export to 2000 journals, was collected for this 
keyword study, only the limit articles of the base. In contrast, the consultation at the base Web of Science, the string "industry 4.0" 2911 articles were found, and with the filter 1027 articles. Research with "circular economy" derived in 3183 , and after the inclusion filter, 1770 articles.

After collecting the articles, exported to VOSviewer software extract the volume of keywords and the most frequent words (Table 3).

Table 3 - Volume of keywords in collected articles.

\begin{tabular}{cccc}
\hline & VOLUME OF KEYWORDS & \\
\hline & SCOPUS & WEB OF SCIENCE & TOTAL \\
\hline INDUSTRY 4.0 & 8000 & 3985 & 11985 \\
\hline CIRCULAR ECONOMY & 12187 & 7677 & 19864 \\
\hline
\end{tabular}

Source: Data VOSviewer.

Table 4 presents the 15 keywords most recurrent in the literature on industry 4.0 and CE. In industry 4.0, the relevance of enabling technologies internet of things, cyber physical systems and big data was found, and similarity to recycling, waste, sustainability and life cycle practices for the CE.

Table 4 - 15 most recurrent keywords in the literature on industry 4.0 and CE.

\begin{tabular}{c|c|c|c}
\hline \multicolumn{4}{c}{ RECURRENT KEY WORDS IN LITERATURE } \\
\hline INDUSTRY 4.0 & \multicolumn{2}{c}{ CIRCULAR ECONOMY } \\
\hline SCOPUS & WEB OF SCIENCE & SCOPUS & WEB OF SCIENCE \\
\hline Industry 4.0 & Industry 4.0 & Circular economy & Circular economy \\
\hline Embedded systems & Internet & Article & Sustainability \\
\hline Manufacture & Big data & Recycling & China \\
\hline Internet of things & Systems & Waste management & Management \\
\hline Cyber physical system & Cyber-physical systems & $\begin{array}{c}\text { Sustainable } \\
\text { development }\end{array}$ & Energy \\
\hline Big data & Future & Economics & Life-cycle assessment \\
\hline Industrial revolutions & Design & Life cycle & Waste \\
\hline Industrial research & Management & Priority journal & Design \\
\hline Cyber-physical systems & Internet of things & $\begin{array}{c}\text { Environmental } \\
\text { impact }\end{array}$ & Recycling \\
\hline Decision making & Framework & Sustainability & Performance \\
\hline Smart manufacturing & Model & Life cycle analysis & Systems \\
\hline Smart factory & Things & Waste disposal & Industrial ecology \\
\hline Automation & Challenges & Life cycle assessment & Framework \\
\hline Internet of things (IoT) & Architecture & $\begin{array}{c}\text { Life cycle assessment } \\
\text { (LCA) }\end{array}$ & System \\
\hline Distributed computer & Performance & Procedures & Challenges \\
\hline
\end{tabular}

Source: Data VOSviewer. 
To check the concepts that are worked on by both industry 4.0 and the CE, articles were collected through the search strings for the integration of the Table 5. Most integration articles are dated 2017, 2018 and 2019, and the total volume of key words in the integration is 233 words.

Table 5 - Volume of articles on integration between industry 4.0 and EC.

\begin{tabular}{ccc|}
\hline QUANTITY OF ARTICLES & \\
\hline STRING DE BUSCA & SCOPUS & WEB OF SCIENCE \\
\hline "INDUSTRY 4.0" AND "CIRCULAR ECONOMY" & 21 & 15 \\
\hline "SMART INDUSTRY" AND "CIRCULAR ECONOMY" & 0 & 0 \\
\hline "ADVANCED MANUFACTURING" AND "CIRCULAR \\
ECONOMY"
\end{tabular}

Source: The authors.

The occurrence number and the strength of the integrated words are shown in Table 6. Highlight that, due to the low volume of publications, no filters were used to collect data from integration articles, as well as limiting, the mapping of the keywords was created with all the articles of the Scopus and Web of Science, considering possible duplicate articles.

Table 6 - 15 most recurrent keywords of integration in the literature.

\begin{tabular}{ccc}
\hline INTEGRATION & OCCURRENCE & STRENGHT \\
\hline Industry 4.0 & 18 & 117 \\
\hline Industrial economics & 8 & 89 \\
\hline Sustainable development & 4 & 68 \\
\hline Environmental impact & 3 & 63 \\
\hline Supply chain management & 3 & 62 \\
\hline Information management & 3 & 59 \\
\hline 3-D printing & 2 & 54 \\
\hline 3-D printers & 2 & 54 \\
\hline 3D printing & 2 & 54 \\
\hline Additive manufacturing & 2 & 54 \\
\hline Advanced manufacturing technologies & 2 & 54 \\
\hline Advanced manufacturing technology & 2 & 54 \\
\hline Cast iron & 2 & 54 \\
\hline Circular economy & 14 & 54 \\
\hline Design/methodology/approach & 2 & 54 \\
\hline
\end{tabular}

Source: Data VOSviewer.

It is noticed that of the 15 most latent words of integration, the word industry 4.0 has the highest level of occurrence and strength, followed by industrial economics. The words 
industry 4.0, information management, 3-d printing, 3-d printers, 3d printing, additive manufacturing, advanced manufacturing technologies and advanced manufacturing technology are related to the situation of industry 4.0 ( 8 of the 15 most relevant). In the CE framework, there are 4 associated words in the integration: circular economy, industrial economics, sustainable development and environmental impact. The word design/methodology/approach was categorized as a method to perform the integration, and supply chain management and cast iron, as application contexts, being separated in the analysis. Therefore, despite the volume of keywords be more related to industry 4.0, mainly enabling technologies, the concepts of industry 4.0 and CE presented complementarity.

To measure a possible level of integration between industry 4.0 and CE, the level of occurrence and strength were crossed, in a correlation matrix between the concepts (Table 7). The literature that studies industry 4.0 features $\mathrm{CE}$ word registration, at an occurrence level of only 7 times in 1612 articles, with a force of 91 at the base Scopus. In Web of Science has an occurrence of 3 times in 1027 journals and a strength of 40. In reverse, journals investigating the CE, but hold the word industry 4.0, there are 7 times in 2000 articles and a force of 82 on Scopus, and an occurrence of 4 times in 1770 documents, with a strength of 35 in the Web of Science.

Table 7 - Industry 4.0 and CE correlation matrix.

\begin{tabular}{|c|c|c|c|c|c|c|c|c|}
\hline & \multicolumn{4}{|c|}{ SCOPUS } & \multicolumn{4}{|c|}{ WEB OF SCIENCE } \\
\hline & \multicolumn{8}{|c|}{ KEYWORDS } \\
\hline & \multicolumn{2}{|c|}{$\begin{array}{c}\text { INDUSTRY } \\
4.0\end{array}$} & \multicolumn{2}{|c|}{$\begin{array}{l}\text { CIRCULAR } \\
\text { ECONOMY }\end{array}$} & \multicolumn{2}{|c|}{$\begin{array}{c}\text { INDUSTRY } \\
4.0\end{array}$} & \multicolumn{2}{|c|}{$\begin{array}{l}\text { CIRCULAR } \\
\text { ECONOMY }\end{array}$} \\
\hline CONTEXT & 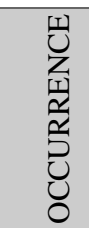 & 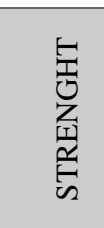 & 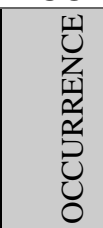 & 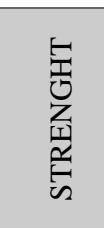 & 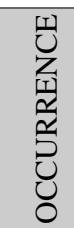 & 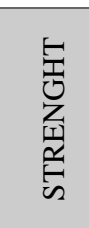 & 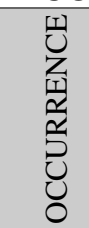 & 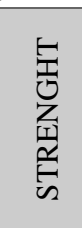 \\
\hline INDUSTRY 4.0 & 887 & 10345 & 7 & 91 & 539 & 1717 & 3 & 40 \\
\hline $\begin{array}{l}\text { CIRCULAR } \\
\text { ECONOMY }\end{array}$ & 7 & 82 & 1244 & 20546 & 4 & 35 & 1082 & 7843 \\
\hline
\end{tabular}

Source: Data VOSviewer.

The occurrence of the word of integration and its strength, comparatively the occurrence of the word industry 4.0 and $\mathrm{CE}$, and in view of the number of articles, it's a very small volume, currently indicating a low level of integration. Furthermore, when evaluating the set of most latent words of the concepts separately (Table 4), the results of the keywords 
mention that is not found in industry 4.0 research (the least in the first 15 words), the presence of themes, circularity strategies, policies and concepts. It is also identified, in the most relevant CE keywords, a focus on pure sustainability, without connection with other propositions or areas.

The academic literature indicates that the two concepts are integrated, providing synergies during their execution, however, at a very early stage of studies. It is indicated that this relationship is more focused on industry 4.0 towards the EC, than the deployment of the EC towards industry 4.0. Figure 2 shows that enabling technologies are support points for the EC, what was not observed how circular organizations can favor the realization of industry 4.0 .

Figure 2 - Keyword map of industry 4.0 and CE integration

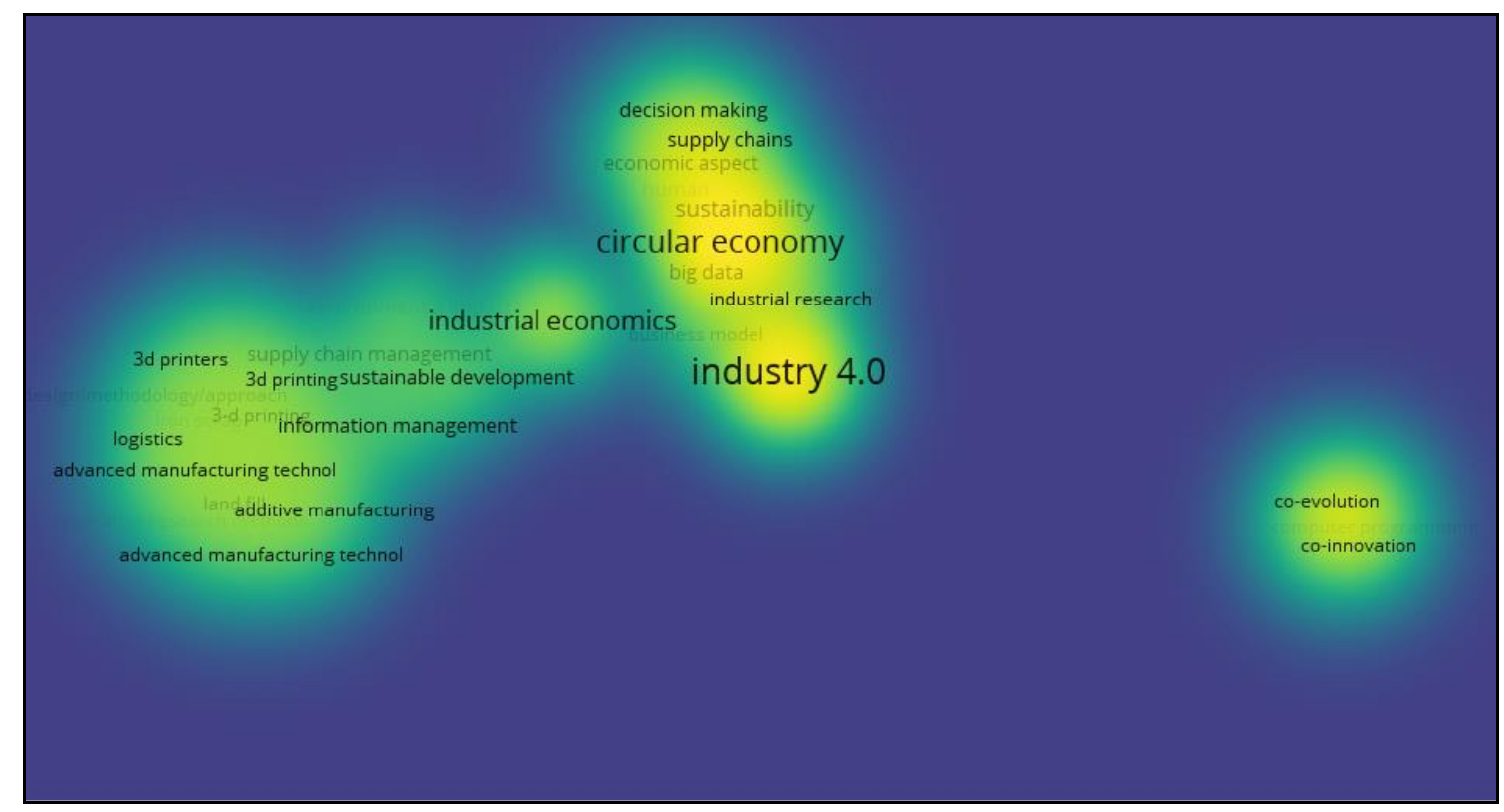

Source: VOSviewer.

Stand out, despite originating from different movements and with more targeted synergistic gains, industry 4.0 can help facilitate, streamline and make CE precepts more efficient, moving towards an integrated and sustainable supply chain, as well as corroborating the decrease in the volume of waste of industrial activity and gains in the economy of companies. Contributions of how the CE can simplify the deployment of industry 4.0 demand studies, since this relationship is not yet clear in the literature.

Therefore, studies with cases of implantation between the two concepts, investigations that propose to discuss facilitators and barriers of the industry 4.0 and $\mathrm{CE}$, and quantitative 
research to measure the level of integration, both in developed and developing countries, are welcome to the academy.

\subsection{Term occurrence network (Keywords)}

Bearing in mind that there is integration between the concepts of industry 4.0 and the $\mathrm{CE}$, the keywords from the VOSviewer were crossed, to identify study possibilities. Initially, $20 \mathrm{CE}$ words were crossed with 17 from industry 4.0, chosen with an occurrence level of at least 5 times among the collected articles, and that they had a complete formation of the word. After this crossing, only keywords that had not been published in at least one of the intersections were filtered, whose result is described in Table 8. At this time, to recognize research opportunities, priority was given to collection in the Web of Science database, due to have a greater volume of articles directed to the engineering area.

Table 8 - Cross between keywords.
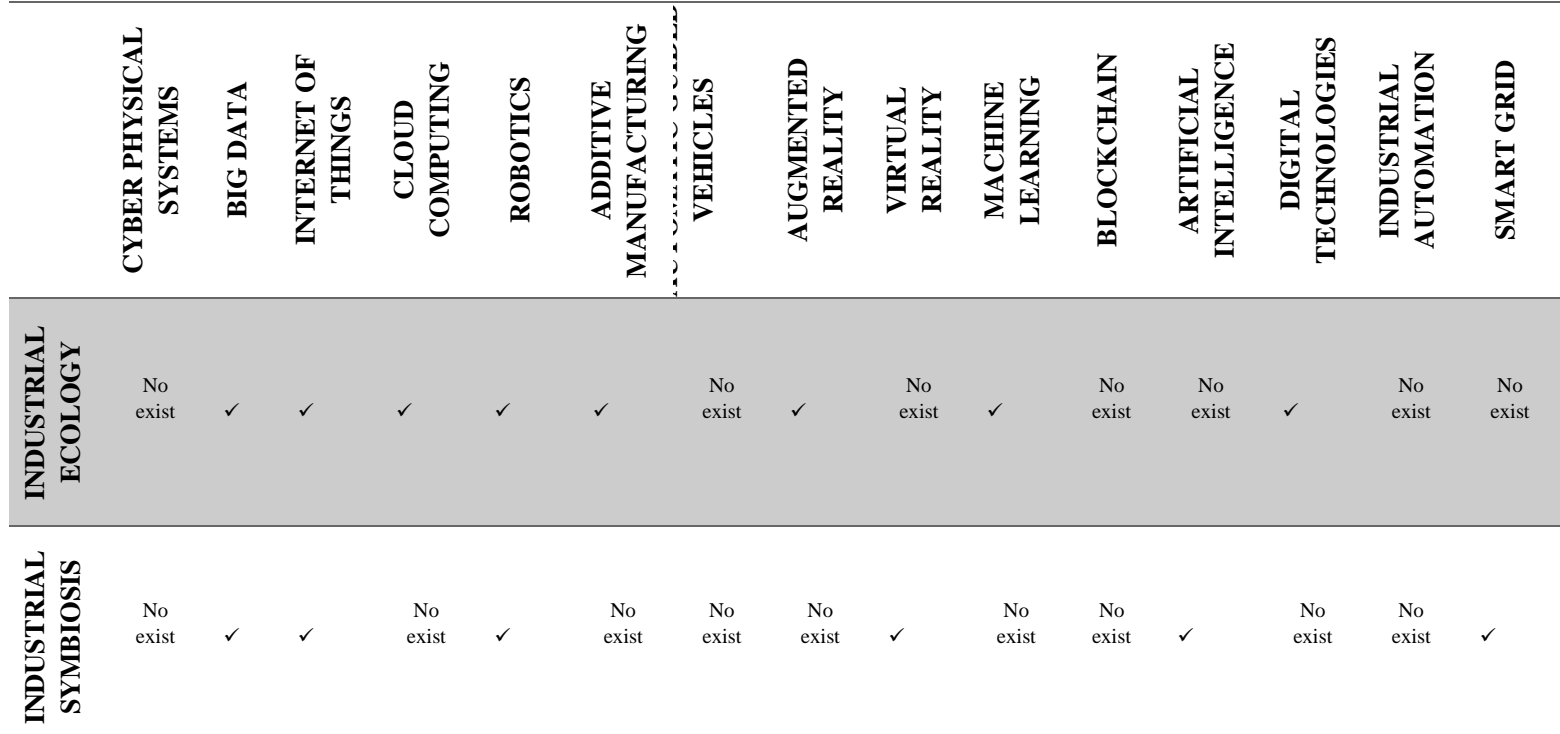

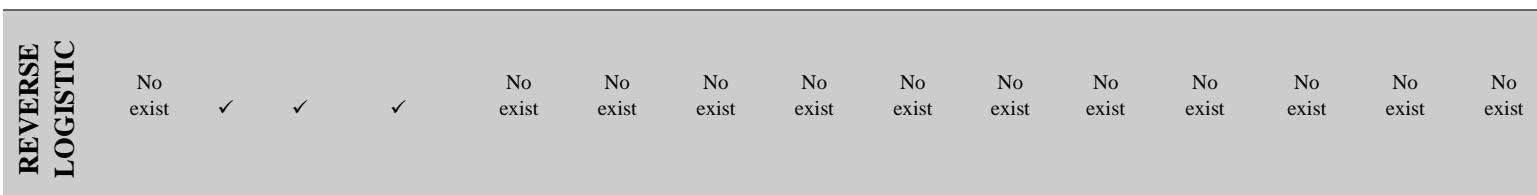

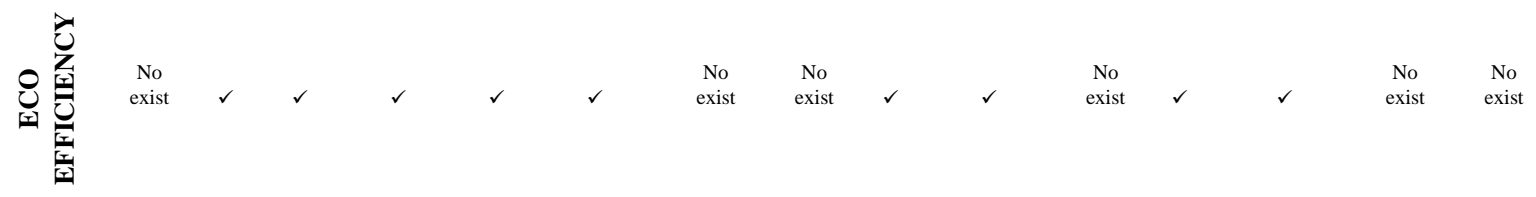




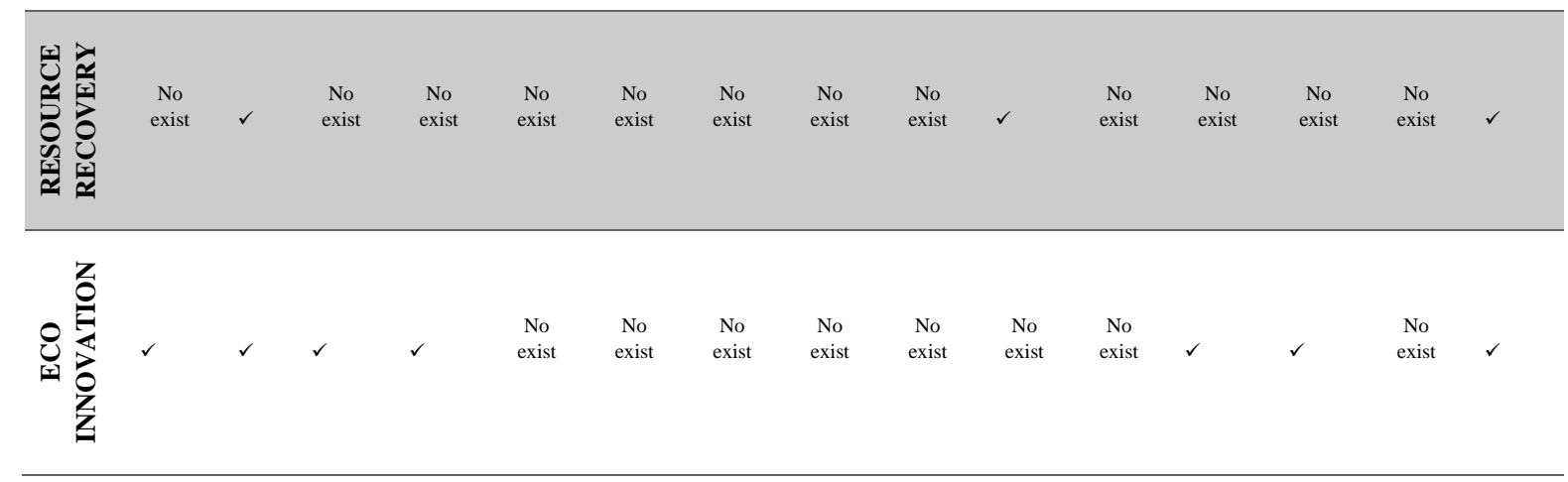

Source: The authors.

The cross between cyber physical systems and eco innovation resulted in only 1 article in the literature, which signals research potential between the two keywords. In the keyword big data there are no studies between this technology and reverse logistic. The word internet of things presents a small volume of articles published from the intersection, 1 publication for industrial ecology, reverse logistic and eco innovation, 2 for industrial symbiosis and 3 for eco efficiency. In the integration between cloud computing and reverse logistic there is only one study in the literature with the intersection of the two keywords. The words robotics and industrial ecology only result in the journal "The Industrial Ecology of Emerging Technologies" published. There is no intersection between automatic guide vehicles, virtual reality, blockchain, industrial automation and the chosen CE keywords, pointed a gap in the literature. It was observed that augmented reality is related to industrial ecology only in 1 publication.

At the crossroads of machine learning + eco innovation and machine learning + resource recovery, there are 2 and 1 articles published respectively. The artificial intelligence, eco efficiency and eco innovation integration has only 1 and 3 publications in that order. Between digital technologies and industrial ecology, and eco efficiency there is 1 academic publication for each intersection, but for the word eco innovation there are 2 publications. For smart grid there is 1 publication on the industrial symbiosis theme and eco innovation, and 2 for resource efficiency.

It is emphasized that even where there are intersections, the number of publications in the literature is low, approximately, in most crossings, of a maximum of 3 articles. Reverse logistics remains the keyword with the least integration with the technologies of industry 4.0, despite the relevance of its practice for the control of material flow to the CE. 
Substantially, big data intersects with all CE keywords, being the technology best explored in the literature. The volume of studies that works with big data and CE grows in academia, within contexts, practices and multiple methods. IoT and cloud computing stand out after the big data study.

To date, technologies such as physical cyber systems, augmented and virtual reality, and additive manufacturing have obtained few studies with $\mathrm{CE}$ keywords, pointing out the demand for future research, fundamentally in studies aimed at reverse logistics and resource recovery.

Eco efficiency, industrial ecology and eco innovation are the themes that the literature develops the most, by integrating with industry 4.0 technologies. Although there are published materials involving the subject, consider that the topic needs further investigation, due to the restricted number of articles published.

Not found in the consulted academic literature, research that linked blockchain, automated guided vehicles (AGV), and industrial automation to the keywords CE. Thus, additional studies are also considered to identify if, specifically at this intersection, there are potential research.

In short, studying the technologies of industry 4.0 together with industrial ecology, industrial symbiosis, reverse logistic, eco efficiency, resource recovery and eco innovation offer research opportunities to increase the volume of studies integrating industry 4.0 and the CE.

\subsection{Analysis of the integration of industry 4.0 and $C E$}

The study of keywords is rich in allowing varied crosses, from which future research opportunities may arise. Therefore, given the result of the VOSviewer software, the literature review, and the crossings made in the previous items, are pointed out below some gaps that the literature presents.

\section{Big data}

Data analysis tools are required to virtual interdisciplinary collaboration between researchers in the field of industrial ecology. Furthermore, big data helps to develop of more realistic complex system models, helping ecologists to understand the environmental 
implications of the industrial system (XU; CHAI; LIANG, 2015). The life cycle analysis literature can also benefit from this industry 4.0 technology (ROSS; CHEAH, 2019).

Big data will provide support to expand carbon capture and storage, that mitigates the global greenhouse effect. Therefore, extracting opinions from popular people, organizations and countries is recommended (ZHANG; HUISINGH, 2017). In addition, due to the complexity, diversity and dynamics of waste sources, big data is a promising research approach, mainly, in the formation of information banks of materials for the practice of IS (SONG et al., 2017).

Conti and Orcioni (2019) there are many possibilities to study the positive impacts of big data, such as the use of data in product traceability for the execution of reverse logistics. Studies applying big data are pointed out by Mavi, Saen and Goh (2019) for country ecoefficiency assessment.

Considering economic viability, adequacy of resources and environmental acceptance, the big data allows the assessment of resources to be recovered, providing the economy of resources recommended by the CE (KANG et al., 2018). Munodawafa and Johl (2019) point out that the study of big data and eco innovation need explorations of mixed research methods, of comparative character, and longitudinal to analyze the effects on the dimensions of product, service, marketing and on the organization.

\section{Cloud computing}

Cloud computing has been proposed in industrial ecology laboratories in Japan and Australia, in order for users to use a large amount of data to personalize their environmental demands (LENZEN et al., 2014; WAKIYAMA et al., 2020). This technology supported decision-making by SmartHome manufacturers, in terms of eco efficiency of products (KIRKHAM et al., 2014).

Cloud computing is a useful to increase eco innovation. Eco innovation lacks market data to be implemented, so, green online marketing information in cloud influence business performance (PISTOL; TONIS, 2017).

IoT

IoT allows knowledge interoperability between companies in an eco-industrial park, implying smart decision making (ZHANG et al., 2017). It is an effective methodology for 
monitoring sustainability, to explore local resources, including those susceptible to symbiotic exchange (GARCIA-MUINÃ et al., 2019).

Like symbiosis, reverse logistics benefits from IoT. Thurer et al. (2019) proposes that studies for the elaboration of optimization methods are essential, intending to dynamically determine the layout of the collection points for reverse materials.

More work is required to map the eco-efficiency of smart agriculture, in this sense, IoT technology can be operated (ROSE; CHILVERS, 2018). Facilitating factors for IoT should be identified in the future for the implementation of smart networks, integrating technology and sustainability to reduce demand for electricity and to promote the efficient use of water (GONZÁLEZ-AMARILLO, CÁRDENAS-GARCÍA, MENDOZA-MORENO, 2018).

\section{Robotization}

New areas of research are requested so that industrial ecology understands the social implications, technological and environmental aspects of robotization (ALLENBY, 2009). On social implications, Rose and Chilvers (2018) point out that robotization has unintended social consequences, unforeseen and unwanted, then, needs to be ascertained.

\section{Additive manufacturing}

Industrial ecology can contribute to studies to develop methods and tools that guarantee production quality, with parts manufacturing using additive manufacturing (YI et al., 2020). As additive manufacturing disseminates, the generation of optimized structures is a relevant issue that affects the eco efficiency of the parts produced (DÍAZ LANTADA et al., 2017; MAMI et al., 2017).

\section{Augmented and virtual reality}

Augmented reality solutions are pleaded for offering business opportunities to the industry (SHAHROKNI, 2015), and virtual reality for helping to IS (NADERI et al., 2019). Gabajová et al. (2019) virtual reality can be explored for training in any area of industrial production, in particular, to train employees and pass on eco-efficiency procedures.

\section{Machine learning}


Few studies have used machine learning, being valid its expansion to interpret patterns in the data and predict unknown variables (FROEMELT; BUFFAT; HELLWEG, 2019). Machine learning can be used to measure and quantify the ecological footprint, water footprint and land use in assessing sustainability (ABDELLA, 2020).

Refine forecasting models with the application of machine learning, to reflect the dynamics of resource recovery and to optimize the quantity and quality of recovered resources, are recommended by Adeogba et al. (2019).

\section{Artificial intelligence}

It is used in the construction of methodologies, tools, and procedures to improve ecoefficiency. Future work can be oriented to this technology for small companies (NADERI et al., 2019). Applying artificial intelligence, Timma, Blumberga and Blumberga (2015) created a conceptual methodology for the diffusion of eco innovation, which demands studies to be extended to other engineering problems, with combined and mixed methods.

Eglash et al. (2020) expects new research to discuss the social role of artificial intelligence, and not only the focus of green technology, like what happens in articles dealing with CE and IS.

\section{Smart grid}

Kuznetsova, Zio and Farel (2016) suggest research that creates optimization models for the distribution and use of industrial electricity among symbiotic partners, predicting future supply and price variations. To model real energy prices, smart grid can be used in resource recovery installation, making it more efficient (PÓVOA et al., 2017).

The energy sector presents ecological problems, therefore, propositions of eco innovations, involving smart grid in energy monitoring, with real-time data to help companies distribute, are recommended by Ghazal et al. (2016).

Based on the intersections in Table 8, that there were no academic studies at certain intersections, it is proposed as contribution of this work some combinations and opportunities for future research. 
Table 9 - Combination and research opportunities.

\begin{tabular}{|c|c|}
\hline $\begin{array}{c}\text { SEARCH } \\
\text { COMBINATION }\end{array}$ & RESEARCH OPPORTUNITIES \\
\hline $\begin{array}{l}\text { Industrial ecology and } \\
\text { industry } 4.0 \text { technologies }\end{array}$ & $\begin{array}{l}\text { 1) Investigate how CPS creates conditions for greening of factories; } \\
\text { 2) Understand how industrial robotization forms a new study scenario for } \\
\text { industrial ecology; } \\
\text { 3) Study in which aspects AGV collaborate for an ecological distribution of the } \\
\text { manufacturing plant; } \\
\text { 4) Test whether virtual reality simulation simplifies the learning and } \\
\text { implementation of ecological practices in industries; } \\
\text { 5) Research under which determinants the application of artificial intelligence } \\
\text { results in greener industrial operations. }\end{array}$ \\
\hline $\begin{array}{l}\text { Industrial symbiosis and } \\
\text { industry } 4.0 \text { technologies }\end{array}$ & $\begin{array}{l}\text { 1) Indicate how CPS can collaborate with computational entities in the search to } \\
\text { effect the exchange of resources in the symbiotic process; } \\
\text { 2) Present structures on how cloud computing will provide online resource sharing } \\
\text { platforms, and how these can reduce partner negotiation costs; } \\
\text { 3) Study how the robotization of the industry simplifies the selection of exchange } \\
\text { materials; } \\
\text { 4) Check if the additive manufacturing supports IS, in the sense that the exchange } \\
\text { resources, to meet customer specifications, they may need to print additional } \\
\text { materials; } \\
\text { 5) Investigate how AGVs can reduce transport costs when sending exchange } \\
\text { material; } \\
\text { 6) Explore at what points virtual reality can build a simulation of the IS network, } \\
\text { before the start of its creation; } \\
\text { 7) Understand the contributions that machine learning makes in the mapping of } \\
\text { material flow and waste sorting; } \\
\text { 8) Understanding drivers, barriers, and benefits of digital technologies to IS. }\end{array}$ \\
\hline $\begin{array}{c}\text { Reverse logistic and } \\
\text { industry } 4.0 \text { technologies }\end{array}$ & $\begin{array}{l}\text { 1) Explore the impacts of CPS implementation on reverse logistics; } \\
\text { 2) Examine how robotization supports the selection, movement and loading of } \\
\text { materials that will return to the manufacturing point (reverse); } \\
\text { 3) Check if the implementation of additive manufacturing, for performing local } \\
\text { printing and change inventory and supply chain suppliers, may reduce the volume } \\
\text { of reverse material in factories; } \\
\text { 4) Propose strategies for massification the use of AGV in reverse logistics, } \\
\text { directing studies to countries with problems in collecting material and lower } \\
\text { recycling rate; } \\
\text { 5) Extend studies that assess how augmented reality supports the storage and } \\
\text { movement of reverse materials; } \\
\text { 6) Research where virtual reality facilitates return procedures for hazardous } \\
\text { materials, and compliance with regulations; } \\
\text { 7) Explore cases of application of machine learning and artificial intelligence in } \\
\text { reverse logistics, formulating standard transport routes, with lower cost and } \\
\text { environmentally friendly; } \\
\text { 8) Expand research on digital technologies and automation, aiming to enable } \\
\text { better results in the reverse logistics of toxic packaging electronic waste. }\end{array}$ \\
\hline $\begin{array}{l}\text { Eco efficiency and } \\
\text { industry } 4.0 \text { technologies }\end{array}$ & $\begin{array}{l}\text { 1) Investigate from which perspectives the real-time monitoring of CPS provides } \\
\text { the eco-efficiency of companies; } \\
\text { 2) Measure under which conditions AGVs reduce pollutants and increase the eco } \\
\text { efficiency of the plant; } \\
\text { 3) Analyze which elements of augmented reality could be added to the production } \\
\text { line, to visualize eco efficient processes; } \\
\text { 4) Understand which industrial automation tools can be aligned with the search for } \\
\text { eco efficiency of global chains; }\end{array}$ \\
\hline
\end{tabular}


5) Study how smart grid technology, installed in generating plants, transmission networks, and factories, provides eco-efficiency for renewable energy sources.

1) Indicate the impacts and limitations of CPS connectivity on the ability to recover productive resources;

2) Exemplify, through the methodology of case studies, situations that the IoT will collaborate in locating the recovered material on the manufacturing line;

3) Propose strategies for the company to expand the cloud storage of resource recovery procedures;

4) Demonstrate ways that robotization and industrial automation assist in the selection and classification of hazardous materials, avoiding human contact during the recovery process;

5) Explain how additive manufacturing can add missing materials to recovery items, speeding up the process;

6) Research the results of virtual reality in resource recovery, preferably in the precision of material cutting processes, and storage simulation;

Resource recovery and 7) Study how augmented reality can be used to raise awareness of the relevance of industry 4.0 technologies resource recovery, and to stimulate the generation of ideas beneficial to recovery;

8) Investigate the assistance that artificial intelligence will bring in the replacement of human labor, during the separation of resources to be recovered, and consequently, reduction of risks to workers' health;

9) Expand research on how digital technologies will reduce the costs of receiving the material to be recovered, its screening, and appropriate treatment, when necessary.

1) Determine how industrial robotization and automation clarifies the implementation of innovative eco industrial processes;

2) Confirm the ability of additive manufacturing to streamline the development and production of innovative eco products;

3) Promote a comparative study between countries, dealing with the structuring of government policies to encourage the generation of eco innovations, in the AGV

Eco innovation and sector;

industry 4.0 technologies 4) Present scenarios of the application of augmented and virtual reality in projects of innovative eco technologies, separating them by phase, of gathering prior and detailed information, development, testing and validation, production and launching to the market;

5) Checking whether machine learning will increase learning patterns of eco innovation, increasing common processes, and resulting in a greater volume of eco innovations created.

Source: The authors.

\section{CONCLUSION}

It is considered that the objective of the article to analyze if the concepts of industry 4.0 and $\mathrm{CE}$ are integrated or disjointed, recognizing in the literature which are the most frequent keywords in this relationship and their occurrence, it was reached.

The concepts of industry 4.0 and CE are integrated and can be developed together in the literature and by the business community, although, academic research about the interconnection between these concepts is in an initial stage and in a disjointed way. 
The theoretical review of this article addressed enabling principles and technologies of industry 4.0, and schools of thought, RESOLVE structure, and CE cycles. A framework was also proposed to visualize the interconnection between enabling technologies and CE schools, that can be teased and transformed for further investigations.

Knowing that the study of industry 4.0 is mainly related to enabling technologies, and for the CE these are matters of recycling, waste management, life cycle and sustainability, industry 4.0 and $\mathrm{CE}$ concepts can be worked in an integrated way, however, due to the low number of occurrences of the integration word and its strength, as well as studying the network map, a low current level of integration is considered. It is indicated that this relationship is more focused on industry 4.0 towards the $\mathrm{CE}$, than the reverse.

Integrate studies of industry 4.0 technologies with the keywords of the CE (industrial ecology, industrial symbiosis, reverse logistics, eco efficiency, resource recovery and eco innovation) is a possibility to increase the volume of studies in the literature between industry 4.0 and CE.

In general, the literature still lacks an investigation process among the concepts proposed in this article, particularly in exploring how the CE can simplify the deployment of industry 4.0, and in investigating the research opportunities indicated in Tables 8 and 9.

\subsection{Research contributions for academics and managers}

This work contributes to business managers in the sense that it facilitates the understanding that industry 4.0 and CE can be worked together. The result of the keywords will guide which skills, strategies, technologies and fundamentals, the company will have to develop to effect the CE, through industry 4.0.

Companies that practice integration will simplify the implementation of the CE, essentially achieving economic and environmental gains from waste management. For using industry 4.0 technologies, towards $\mathrm{CE}$, there will be synergies that will allow the organization to achieve the benefits of both concepts simultaneously.

For academic research, contributed with one more study on the integration of industry 4.0 and CE, that are few in the literature. Keywords were also mapped, that until then, had not been developed in existing integration articles, besides proposing a framework that can be transformed and signal research opportunities. It is also noted that big data technology has greater current research potential, and that CPS technologies, augmented and virtual reality, 
and additive manufacturing need further studies, in particular, those focused on reverse logistics and resource recovery. In addition, a greater number of enabling technologies were considered in this study and precepts of industry 4.0 of the current disposition in the studies of integration of the literature, not just checking some technologies, like IoT, CPS, big data and additive manufacturing.

\subsection{Limitations and future research}

It is an exploratory study, with little depth of investigation of the variables, furthermore, because of the fact that there are few studies on the integration, comparative weights become restricted. Due to its theoretical nature, it is impossible to statistically generalize the data, and checking if the keywords found are actually used in industrial organizations.

The search strings are restricted and the "article" filter for industry 4.0 and CE may have restricted the analysis, may dispense interesting conference or review materials. Although being the most usual, the study was limited to the use of two databases, and to check if there was published research material (Table 8), only the Web of Science database was used.

As future research it is suggested: a) the application of other tools to measure the level of integration, b) extension of the review study to discover other possible integration points, and c) conducting an empirical study on the topic. It is highlighted that the research opportunities in Table 9 could be converted into themes or hypotheses of qualitative and quantitative studies, theoretical or empirical, and Table 8 indicates, at their intersections, research gaps. In this way, its result in possibilities of deepening the literature on the topic and/or original studies.

\section{Acknowledgement}

This study was financed in part by the Coordenação de Aperfeiçoamento de Pessoal de Nível Superior - Brasil (CAPES) - Finance Code 001. 


\section{Referências}

ABDELLA, G.M. et al. Sustainability assessment and modeling based on supervised machine learning techniques: the case for food consumption. Journal of Cleaner Production, v. 251, n.119661, 2020.

ABERKANE, I.J. From waste to kwaste: on the blue economy in terms of knowledge flow. Spring Proceedings in Complexity, p. 283-290, 2017.

ADEOGBA, E. et al. Waste-to-resource transformation: gradient boosting modeling for organic fraction municipal solid waste projection. ACS Sustainable Chemistry \& Engineering, v. 7, n. 12, p. 10460-10466, 2019.

AHMED, S.; HUANG, B. Control engineering practice in 25 years: a bibliometric overview. Control Engineering Practice, v. 88, p. 16-20, 2019.

ALLENBY, B. The industrial ecology of emerging technologies complexity and the reconstruction of the world. Journal of Industrial Ecology, v. 13, n. 2, p. 168-183, 2009.

BAHRIN, M.A.K. et al. Industry 4.0: a review on industrial automation and robotic. Science \& Engineering, v. 78, n. 6-13, p. 137-143, 2016.

BENDUL, J.C., BLUNCK, H. The design space of production planning and control for industry 4.0. Computers in Industry, v. 105, p. 260-272, 2019.

BLOMSMA, F. Collective 'action recipes' in a circular economy - on waste and resource management frameworks and their role in collective change. Journal of Cleaner Production, v. 199 , p. 969-982, 2018.

BLOMSMA, F., BRENNAN, G. The emergence of circular economy: a new framing around prolonging resource productivity. Journal of Industrial Ecology, v. 21, n. 3, p. 603-614, 2017.

BRESSANELLI, G. et al. Exploring how usage-focused business models enable circular economy through digital technologies. Sustainability, v. 10, n. 639, p. 1-21, 2018. (a)

BRESSANELLI, G. et al. The role of digital technologies to overcome circular economy challenges im PSS business models: an exploratory case study. Procedia CIRP, v. 73, p. 216221, 2018. (b)

CHERTOW, M. R. Industrial symbiosis: literature and taxonomy. Annual Review of Energy and the Environment, v. 25, p. 313-337, 2000.

CHERTOW, M. R. "Uncovering” industrial symbiosis. Journal of Industrial Ecology, v. 11, n. 1, p. 11-30, 2007. 
COLE, R.J. Regenerative design and development: current theory and practice. Building Research \& Information, v. 40, n. 1, p. 1-6, 2012.

CONTI, M.; ORCIONI, S. Cloud-based sustainable management of electrical and electronic equipment from production to end-of-life. International Journal of Quality \& Reliability Management, v. 36, n. 1, p. 98-119, 2019.

DÍAZ LANTADA, A. et al. Design and performance assessment of innovative eco-efficient support structures for additive manufacturing by photopolymerization. Journal of Industrial Ecology, v. 21, p. 179-190, 2017.

DINIS, F.M. et al. Improving project communication in the architecture, engineering and construction industry: coupling virtual reality and laser scanning. Journal of Building Engineering, v. 30, n.101287, 2020.

EGLASH, R. et al. Automation for the artisanal economy: enhancing the economic and environmental sustainability of crafting professions with human-machine collaboration. AI \& Society, v. 35, p. 595-609, 2020.

EHRENFELD, J.; GERTLER, N. Industrial ecology in practice: the evolution of interdependence at Kalundborg. Journal of Industrial Ecology, v. 1, n. 1, p. 67-79, 1997.

ELLEN MACARTHUR FOUNDATION. Infographic: Circular Economy Systems Diagram, 2017. Disponível em: https://www.ellenmacarthurfoundation.org/circulareconomy/infographic. Acesso em 10.05.19.

ELLEGAARD, O.; WALLIN, J.A. The bibliometric analysis of scholarly production: how great is the impact? Scientometrics, v. 105, p. 1809-1831, 2015.

ELLIS, L.A. et al. Patterns of resilience: a scoping review and bibliometric analysis of resilient health care. Safety Science, v. 118, p. 241-257, 2019.

FAROUKHI, A.Z. et al. Big data monetization throughout big data value chain comprehensive. Journal of Big Data, v. 7, n. 1, 2020.

FRANCIS, J.; BIAN, L. Deep learning for distortion prediction in laser-based additive manufacturing using Big Data. Manufacturing Letters, v. 20, p. 10-14, 2019.

FRANK, A.G.; DALENOGARE, L.S.; AYALA, N.F. Industry 4.0 technologies: implementation patterns in manufacturing companies. International Journal of Production Economics, v. 210, p. 15-26, 2019.

FROEMELT, A.; BUFFAT, R.; HELLWEG, S. Machine learning based modeling of households: a regionalized bottom-up approach to investigate consumption-induced environmental impacts. Journal of Industrial Ecology, p. 1-14, 2019. 
GABAJOVÁ, G. et al. Virtual training application by use of augmented and virtual reality under university technology enhanced learning in Slovakia. Sustainability, v. 11, n. 23, 6677, 2019.

GARCIA-MUINÃ, F.E. et al. The paradigms of industry 4.0 and circular economy as enabling drivers for the competitiveness of businesses and territories: the case of an Italian ceramic tiles manufacturing company. Social Science, v. 7, n. 255, p. 1-31, 2018.

GARCIA-MUINÃ, F.E. et al. Identifying the equilibrium point between sustainability goals and circular economy practices in an industry 4.0 manufacturing context using eco-design. Social Science, v. 8, n. 8, 241, 2019.

GATTULLO, M. et al. Towards augmented reality manuals for industry 4.0: a methodology. Robotics and Computer-Integrated Manufacturing, v. 56, p. 276-286, 2019.

GAZZOLA, P.; DEL CAMPO, A.G.; ONYANGO, V. Going green vs going smart for sustainable development: quo vadis? Journal of Cleaner Production, v. 214, p. 881-892, 2019.

GEISENDORF, S.; PIETRULLA, F. The circular economy and circular economic concepts a literature analysis and redefinition. Thunderbird International Business Review, v. 60, n. 5, p. 771-782, 2018.

GEISSDOERFER, M. et al. The circular economy - a new sustainability paradigm? Journal of Cleaner Production, v. 143, p. 757-768, 2017.

GHAZAL, M. et al. Smart plugs: perceived usefulness and satisfactions: evidence from United Arab Emirates. Renewable and Sustainable Energy Reviews, v. 55, p. 1248-1259, 2016.

GHOBAKHLOO, M. The future of manufacturing industry: a strategic roadmap toward industry 4.0. Journal of Manufacturing Technology Management, v. 29, n. 6, p. 910-936, 2018.

GOBBO JÚNIOR, J.A. et al. Making the links among environmental protection, process safety, and industry 4.0. Process Safety and Environmental Protection, v. 117, p. 372-382, 2018.

GONZÁLEZ-AMARILLO，C.A.; CÁRDENAS-GARCÍA，C.L.; MENDOZA-MORENO, M.A. M2M system for efficient water consumption in sanitary services, based on intelligent environment. DYNA, v. 85, n. 204, p. 311-318, 2018.

GU, F. et al. An integrated architecture for implementing extended producer responsibility in the context of Industry 4.0. International Journal of Production Research, v. 57, n. 5, p. 1458-1477, 2019. 
HAFEZALKOTOB, A. et al. An overview of MULTIMOORA for multi-criteria decision making: theory, developments, applications, and challenges. Information Fusion, v. 51, p. 145-177, 2019.

ISSAMAR, F.H.M.K.; ROBERTO, R.L. New and emerging occupational risks (NER) in industry 4.0: literature review. In: INTERNATIONAL ENGINEERING, SCIENCES AND TECHNOLOGY CONFERENCE, 2019, $7^{\text {th. }}$ Anais...v. 8943671, p. 394-399, 2019.

IVANOV, D.; DOLGUI, A.; SOKOLOV. B. The impact of digital technology and industry 4.0 on the ripple effect and supply chain risk analytics. International Journal of Production Research, v. 57, n. 3, p. 829-846, 2019.

JABBOUR, C.J.C. et al. Unlocking the circular economy through new business models based on large-scale data: an integrative framework and research agenda. Technological Forecasting and Social Change, v. 144, 546-552, 2019 (a).

JABBOUR, C.J.C. et al. Who is in charge? A review and a research agenda on the "human side" of the circular economy. Journal of Cleaner Production, v. 222, p. 793 -801, 2019 (b).

JENSEN, J.P.; REMMEN, A. Enabling circular economy through product stewardship. Procedia Manufacturing, v. 8, p. 377-384, 2017.

JIANG, W. et al. Design optimization of confidentiality-critical cyber physical systems with fault detection. Journal of Systems Architecture, v. 107, n. 101739, 2020.

KAMDEM, J.P. et al. Research trends in food chemistry: a bibliometric review of its 40 years anniversary (1976-2016). Food Chemistry, v. 294, p. 448-457, 2019.

KANG, H.S. et al. Smart manufacturing: past research, present findings, and future directions. International Journal of Precision Engineering and Manufacturing - Green Technology, v. 3, p. 111-128, 2016.

KANG, L. et al. Systematic research on the application of steel slag resources under the background of big data. Complexity, n.6703908, p. 1-12, 2018.

KIRKHAM, T. et al. Risk driven smart home resources management using cloud services. Future Generation Computer Systems, v. 38, p. 13-22, 2014.

KOPNINA, H., 2019. Green-washing or best case practices? Using circular economy and Cradle to Cradle case studies in business education. Journal of Cleaner Production, v. 219, p. 613-621, 2019.

KUZNETSOVA, E.; ZIO, E.; FAREL, R. A methodological framework for eco-industrial park design and optimization. Journal of Cleaner Production, v. 126, p. 308-324, 2016. 
LAWAL, I.A. et al. Brief bibliometric analysis of "ionic liquid" applications and its review as a substitute for common adsorbent modifier for the adsorption of organic pollutants. Environmental Research, v. 175, p. 34-51, 2019.

LEE, J.; KAO, H.A; YANG, S. Service innovation and smart analytics for industry 4.0 and big data environment. Procedia CIRP, v. 16, p. 3-8, 2014.

LENZEN, M. et al. Compiling and using input-output frameworks through collaborative virtual laboratories. Science of the Total Environment, v. 485-486, p. 241-251, 2014.

LIEDER, M. et al. Towards circular economy implementation in manufacturing systems using a multi-method simulation approach to link design and business strategy. The International Journal of Advanced Manufacturing Technology, v. 93, p. 1953-1970, 2017.

LIN, K.Y. User experience-based product design for smart production to empower industry 4.0 in the glass recycling circular economy. Computers \& Industrial Engineering, v. 125, p. 729-738, 2018.

LÓPEZ-ROBLES, J.R. et al. 30 years of intelligence models in management and business: a bibliometric review. International Journal of Information Management, v. 48, p. 22-38, 2019.

LU, Y., XU, X. Cloud-based manufacturing equipment and big data analytics to enable ondemand manufacturing services. Robotics and Computer-Integrated Manufacturing, v. 57, p. 92-102, 2019.

LYLE CENTER. History, 2019. Disponível em: 〈https://env.cpp.edu/rs/history-lyle-center.> Acesso em: 18.05.19.

MAMI, F. et al. Evaluating eco-efficiency of 3D printing in the aeronautic industry. Journal of Industrial Ecology, v. 21, p. S37-S48, 2017.

MANAVALAN, E.; JAYAKRISHNA, K. A review of internet of things (IoT) embedded sustainable supply chain for industry 4.0 requirements. Computers \& Industrial Engineering, v. 127, p. 925-953, 2019.

MARQUES, G., PITARMA, R. An internet of things approach for environmental quality management and laboratory activity support. CISTI, 8760876, 2019.

MARTÍN-GÓMEZ, A.; AGUAYO-GONZÁLEZ, F.; LUQUE, A. A holonic framework for managing the sustainable supply chain in emerging economies with smart connected metabolism. Resources, Conservation and Recycling, v. 141, p. 219-232, 2019. 
MASSOD, T.; EGGER, J. Augmented reality in support of industry 4.0 - implementation challenges and success factors. Robotics and Computer-Integrated Manufacturing, v. 58, p. 181-195, 2019.

MAVI, R., SAEN, R.F., GOH, M. Joint analysis of eco-efficiency and eco-innovation with common weights in two-stage network DEA: a big data approach. Technological Forecasting and Social Change, v. 144, p. 553-562, 2019.

MIRABELLA, N.; CASTELLANI, V.; SALA, S. Current options for the valorization of food manufacturing waste: a review. Journal of Cleaner Production, v. 65, p. 28-41, 2014.

MOEUF, A. et al. The industrial management of SMEs in the era of industry 4.0. International Journal of Production Research, n. 56, n. 3, p. 1118-1136, 2018.

MUNODAWAFA, R.T.; JOHL, S.K. Big data analytics capabilities and eco-innovation: a study of energy companies. Sustainability, v. 11, n. 15, 4254, 2019.

NADERI, M. et al. Sustainable operations management for industry 4.0 and its social return. IFAC-Papers on line, v. 52, n. 13, p. 457-462, 2019.

NASCIMENTO, D.L.M. et al. Exploring industry 4.0 technologies to enable circular economy practices in a manufacturing context: a business model proposal. Journal of Manufacturing Technology Management, v. 30, n. 3, p. 607-627, 2019.

NASIR, M.H.A. et al. Comparing linear and circular supply chains: a case study from the construction industry. International Journal of Production Economics, v. 183 (B), p. 443457, 2017.

OKORIE, O. et al. Digitisation and the circular economy: a review of current research and future trends. Energies, v. 11, n. 3009, p. 1-31, 2018.

PISTOL, L.; TONIS BUCEA-MANEA, R. The "7Ps" \& "1G" that rule in the digital world the marketing mix. In: INTERNATIONAL CONFERENCE ON BUSINESS EXCELLENCE. Anais...ICBE, v. 11, n. 1, p. 759-769, 2017.

PÓVOA, P. et al. Modelling energy costs for different operational strategies of a large water resource recovery facility. Water Science \& Technology, v. 75, n. 9, p. 2139-2148, 2017.

RAJPUT, S.; SINGH, S.P. Connecting circular economy and industry 4.0. International Journal of Information Management, v. 49, p. 98-113, 2019.

REDEKER, G.A.; KESSLER, G.Z.; KIPPER, L.M. Lean information for lean communication: analysis of concepts, tools, references, and terms. International Journal of Information Management, v.47, p.31-43, 2019.

ROJAS LUIZ, J.V. et al. Ecodesign field of research throughout the world: mapping the territory by using an evolutionary lens. Scientometrics, v. 109, p. 241-259, 2016. 
ROSE, D.C.; CHILVERS, J. Agriculture 4.0: broadening responsible innovation in an era of smart farming. Frontiers in Sustainable Food System, v. 2, n. 87, 2018.

ROSS, S.A.; CHEAH, L. Uncertainty quantification in life cycle assessments: exploring distribution choice and greater data granularity to characterize product use. Journal of Industrial Ecology, v. 23, n. 2, p. 335-346, 2019.

SALAH, B. et al. Virtual reality-based engineering education to enhance manufacturing sustainability in industry 4.0. Sustainability, v. 11, n. 1477, p. 2-19, 2019.

SAHIMAA, O. et al. Towards zero climate emissions, zero waste, and one planet living testing the applicability of three indicators in Finnish cities. Sustainable Production and Consumption, v. 10, p. 121-132, 2017.

SHAHROKNI, H., et al. Implementing smart urban metabolism in the Stockholm Royal Seaport: smart city SRS. Journal of Industrial Ecology, v. 19, n. 5, p. 917-929, 2015.

SINGH, S.P. et al. Supply chain management, industry 4.0, and the circular economy. Resources, Conservation and Recycling, v. 142, p. 281-282, 2019.

SONG, B. et al. Industrial symbiosis: exploring big-data approach for waste stream discovery. Procedia CIRP, v. 61, p. 353-358, 2017.

SONY, M. Industry 4.0 and lean management: a proposed integration model and research propositions. Production \& Manufacturing Research, v. 6, n. 1, p. 416-432, 2018.

SOUSA JABBOUR, A.B.L. et al. When titans meet - can industry 4.0 revolutionise the environmentally sustainable manufacturing wave? The role of critical success factors. Technological Forecasting and Social Change, v. 132, p. 18-25, 2018. (a)

SOUSA JABBOUR, A.B.L. et al. Industry 4.0 and the circular economy: a proposed research agenda and original roadmap for sustainable operations. Annals of Operations Research, v. 270, p. 273-286, 2018. (b)

STABEL, W.R. The performance economy. Palgrave Macmilan, Basingstoke: UK, 2010.

STOCK, T.; SELIGER, G. Opportunities of sustainable manufacturing in industry 4.0. Procedia CIRP, v. 40, p. 536-541, 2016.

STRANDHAGEN, J.W. et al. The fit of industry 4.0 applications in manufacturing logistics: a multiple case study. Advances in Manufacturing, v. 5, p. 344-358, 2017.

SWAIN, B. Recovery and recycling of lithium: a review. Separation and Purification Technology, v. 172, p. 388-403, 2017.

THURER, M. et al. Internet of things (IoT) driven kanban system for reverse logistics: solid waste collection. Journal of Intelligent Manufacturing, v. 30, n. 7, p. 2621-2630, 2019. 
TIMMA, L.; BLUMBERGA, A.; BLUMBERGA, D. Combined and mixed methods research in environmental engineering: when two is better than one. Energy Procedia, v. 72, p. 300$306,2015$.

TSENG, M.L. et al. Circular economy meets industry 4.0: can big data drive industrial symbiosis? Resources, Conservation and Recycling, v. 131, p. 146-147, 2018.

TSENG, M.L. et al. Pathways and barriers to circularity in food systems. Resources, Conservation and Recycling, v. 143, p. 236-237, 2019.

TUKKER, A., 2015. Product services for a resource-efficient and circular economy - a review. Journal of Cleaner Production, v. 97, p. 76-91, 2015.

VAN ECK, N.J.; WALTMAN, L. Software survey: VOSviewer, a computer program for bibliometric mapping. Scientometrics, v. 84, n. 2, p. 523-538, 2010.

WAHRMANN, D. et al. An autonomous and flexible robotic framework for logistics applications. Journal of Intelligent \& Robotic Systems, v. 93, p. 419-431, 2019.

WAKIYAMA, T. et al. A flexible multiregional input-output database for city-level sustainability footprint analysis in Japan. Resources, Conservation and Recycling, v. 154, $104588,2020$.

WANG, H.; YANG, Y. Neighbourhood walkability: a review and bibliometric analysis. Cities, v. 93, p. 43-61, 2019.

WAN, J. et al. Software-defined industrial internet of things in the context of industry 4.0. IEEE Sensors Journal, v. 16, n. 20, p. 7373-7380, 2016.

XU, M.; CAI, H.; LIANG, S. Big data and industrial ecology. Journal of Industrial Ecology, v. 19, n. 2, p. 205-210, 2015.

YANG, S. et al. Opportunities for industry 4.0 to support remanufacturing. Applied Science, v. 8, n. 1177, p. 2-11, 2018.

YAZDI, P.G.; AZIZI, A.; HASHEMIPOUR, M. An empirical investigation of the relationship between overall equipment efficiency (OEE) and manufacturing sustainability in industry 4.0 with time study approach. Sustainability, v. 10, n. 3031, p. 1-28, 2018.

YI, L. et al. An eco-design for additive manufacturing framework based on energy performance assessment. Additive Manufacturing, v. 33, n.101120, 2020.

ZHAN, Z.H. et al. Cloud Computing resource schediling and survey of its evolutionary approaches. ACM Computing Surveys, v. 47, n. 4, p. 63-63:33, 2015.

ZHANG, C. et al. Knowledge management of eco-industrial park for efficient energy utilization through ontology-based approach. Applied Energy, v. 204, p. 1412-1421, 2017. 
ZHANG, Z., HUISINGH, D. Carbon dioxide storage schemes: technology, assessment and deployment. Journal of Cleaner Production, v. 142, p. 1055-1064, 2017. 